\title{
Correction to: iGlioSub: an integrative transcriptomic and epigenomic classifier for glioblastoma molecular subtypes
}

Miquel Ensenyat-Mendez, Sandra Îñiguez-Muñoz, Borja Sesé and Diego M. Marzese*

\author{
The original article can be found \\ online at https://doi.org/10.1186/ \\ s13040-021-00273-8. \\ * Correspondence: diego.marzese@ \\ ssib.es \\ Cancer Epigenetics Laboratory at \\ the Cancer Cell Biology Group, \\ Institut d'Investigació Sanitària Illes \\ Balears (IdlSBa), Carretera de \\ Valldemosa 79, -1F, 07120 Palma de \\ Mallorca, Spain
}

\section{Correction to: BioData Mining 14, 42 (2021) \\ https://doi.org/10.1186/s13040-021-00273-8}

Following publication of the original article [1], the authors identified an error in the Funding section.

The section currently reads:

The research was supported by the Spain Instituto de la Salud Carlos III (ISCIII) grants: Miguel Servet Project (\#CP17/00188) and AES 2019 Project (\# PI19/01514), the Institut d'Investigació Sanitària Illes Balears (IdISBa) FOLIUM program/Impost turisme sostenible (Govern de les Illes Balears), the Fundación Francisco Cobos, and the Asociación Española Contra el Cáncer (AECC).

The section should read:

The research was supported by the Spain Instituto de la Salud Carlos III (ISCIII) grants: Miguel Servet Project (\#CP17/00188) and AES 2019 (\#PI19/01514) co-funded by ERDF "A way to make Europe", the Institut d'Investigació Sanitària Illes Balears (IdISBa) FOLIUM program/Impost turisme sostenible (Govern de les Illes Balears), the Fundación Francisco Cobos, and the Asociación Española Contra el Cáncer (AECC).

The original article [1] has been corrected.

Published online: 17 November 2021

\section{Reference}

1. Ensenyat-Mendez M, Iñiguez-Muñoz S, Sesé B, Marzese DM. iGlioSub: an integrative transcriptomic and epigenomic classifier for glioblastoma molecular subtypes. BioData Mining. 2021;14:42 https://doi.org/10.1186/s13040-021-00273-8. 